\title{
Spectral and Physical Studies on Some Metal Complexes of Lysine Amino Acid and the Adsorption Properties of Their Nano Oxides
}

\author{
Farid I. El-Dossoki ${ }^{1{ }^{1 *}}$, Sarah. $\operatorname{Rady}^{2}$, Nasser M. Hosny ${ }^{1}$
}

${ }^{1}$ Chemistry Department, Faculty of Science, Port-Said University, Port-Said, Egypt

${ }^{2}$ Laboratory Specialist, Faculty of Pharmacy, Port-Said University, Port-Said, Egypt

* Corresponding author: feldossoki64@ @sci.psu.edu.eg

\begin{abstract}
Lys-Zn, Lys-Co, Lys-Cu and Lys-Ni complexes prepared by reaction of metal acetates with lysine (Lys). Complexes were characterized by elemental analysis $(\mathrm{C}, \mathrm{H}, \mathrm{N}$ and M), (UV/Vis) electronic spectra, FT-IR, 1H-13C NMR, (ESR) spectroscopy, Thermal analyses (TGA) and magnetic moments measurements. Physical studies were applied on the synthesis complexes such as solubility, density, molar volume, refractive index and excess refractive index and electronic (UV/Vis) spectra measurements. Nickel oxide nanoparticles synthesized from calcinations of complex at $800{ }^{\circ} \mathrm{C}$. Nanoparticles were characterized by (XRD) and (TEM). Molecular size is at range 43-52 $\mathrm{nm}$. Nanoparticles were used to remove dyes from aqueous solution such as methylene blue (MB) and the percent of removal is $96 \%$. The best model which represents the adsorption of MB is Langmuir isotherm. The best model for adsorption kinetic of MB ispseudo-second-order model with determination coefficient $\left(\mathrm{R}^{2}\right)$ close to the unity.
\end{abstract}

Keywords:

Solubility; Molecular precursors; NiOnanoparticles; Adsorption.

\section{INTRODUCTION}

Proteins and genes were affected by Poly lysine, which is a based block of copolymers. Polyelectrolytes and proteins interact via electrostatic interactions to prepare hybrid complexes which have different morphologies, stoichiometries, shapes and architectures. This system is biofunctional with applications in design and development of biopharmaceuticals and in biosensors [1]. These materials used as nano carriers with enhanced properties and exhibit both $\mathrm{pH}$ and ionic strength-dependent [2].Polyion complexes micelles with coreshell morphology were formed by interaction of ionic block copolymers with ionic biopharmaceuticals such as genes and proteins [3].

Nanoparticles of metal oxides manufactured in large scale because of their applications in industrial [4]. Metal oxides are semiconductor which investigated for a long time and used as gas sensors, humidity andcatalysis[5]. Nanoparticles of metal oxide have potential to replace noble metal catalysts for carbon monoxide oxidation [6]. Nano-fluids of metal oxide nanoparticles have excellent thermal conductivity suitable for their applications as heat transfer fluids in machine tools.Different techniques have been applied to prepare metal oxide thin films [7-8]. 
Nanometer-sized particles have studded due to their nano-size dependent properties and very high potential for several applications [9]. The morphology of the particles have important effect on properties [10]. Single-molecule precursors have been used to prepare high-quality nanoparticles [11].

Refractive index measurements and density measurements of solutions used to study the solute-solvent interactions. Refractive index measurements were able to give good informations about the nature of molecular interactions of liquid mixtures or pure liquids. The separation process of amino acids in aqueous solution depended on crystallization or precipitation methods. Density measurements are used to study the structure and interaction of mixtures [12]. Thermodynamic parameters of complexes in solutions give informations about the molecular interactions. The solvent plays a dramatic role on the out-come of chemical reactions. To control processes involving the complexes, the knowledge of their thermophysical and thermodynamic properties is required.

This work study synthesis, characterizes, physical and biological properities of lysine metal complexes and adsorption prosperities of the synthesisednanoparticles molecules.

\section{EXPERIMENTAL}

\subsection{Chemicals}

Lysine was purchased from ADWIC, metal acetate, ethanol and Methylene Blue purchased from Merck.

\subsection{Apparatus and methods}

Elemental Analysiswas measured by automatic (Elemental CHNS Analysis AnalyserVario-EL Model 111 Germany) [13]. The electronic spectra were determined using (JASCO Model V-630) UV2 Unicam UV/Vis. Magnetic moment measurements have been measured by Sherwood scientific magnetic balance using the following equations: $\chi_{\mathrm{g}}=\mathrm{Cl}\left(\mathrm{R}-\mathrm{R}_{\mathrm{o}}\right) / 10^{3} \mathrm{~m} \ldots .(1) ; \chi_{\mathrm{m}}=\chi_{\mathrm{g}} \cdot \mathrm{M}_{\mathrm{wt}} \cdot 10^{-3} \ldots . .(2) ; \mu_{\mathrm{eff}}=2.84 \sqrt{ } \chi \mathrm{mT}$

(Where $\chi_{\mathrm{g}}$ is the mass susceptibility per gm sample; $\mathrm{C}$ is the constant of the instrument; 1 is the sample length in $\mathrm{cm} ; \mathrm{m}=$ weight of sample; $\chi_{\mathrm{g}}=$ molar susceptibility, $\mu_{\text {eff }}=$ effective magnetic moment and $\mathrm{T}$ is the absolute temperature). TGA measurements record on (Disfrantial Thermal Analyser Thermo Gravimetric Analyser DTG $60 \mathrm{H})$. IR spectra recorded by (FT/IR- 4100 type A) Mattson Spectrometer. XRD pattern Philips X PERT-PRO with Ni filtered $\mathrm{Cu} \mathrm{K} \alpha(\lambda=1.5405 \AA)$ radiation. TEM images have been taken on CM 20 PHILIPS electron microscopes. ${ }^{1} \mathrm{H}^{13}{ }^{13} \mathrm{C}$ NMRSpectra was record on (NMR VARIAN $200 \mathrm{MHz}$ Nano Colour Model 300D). The density of saturated solution of complexes in (ethanol-water) solvent of ethanol different mole fractions in rang (0.00/0\%-1.00/100\%) measured using $5 \mathrm{ml}$ Pyknometer.The refractive index of solutions measured using Abbe Refractometer Model 2WAJ). Electronic spectra of lysine metal complexes which dissolved in different mole fraction of ethanol water at ranges $(0.00,0.235$ and 1.00) have been recorded on (JASCO Model V-630).

\subsection{Preparation of the precursor}

The complex was synsised by adding $(2$ mole) of the metal acetate in $10 \mathrm{ml}$ distilled water mixed to (1 mole) of lysine were dissolved in $10 \mathrm{ml}$ ethanol alcohol. The mixture has been refluxed for $4 \mathrm{hrs}$, then concentrated by evaporation at $50{ }^{\circ} \mathrm{C}$. A precipitate is formed on addition of excess absolute ethanol. It has filtrated off, washed by ethanol and distilled water then, dried at $100{ }^{\circ} \mathrm{C}$ [14].

\subsection{Synthesis of NiO nanoparticles}

1 gram of $\mathrm{Ni}$ (II) complex was ignited in a muffle furnace for $2 \mathrm{hrs}$ at $800{ }^{\circ} \mathrm{C}$ in air. NiOnanoparticles were synsised. 


\subsection{Adsorption of methylene blue}

Nanoparticles were used to remove $\mathrm{MB}$ dye from aqueous solvent. A weight of $\mathrm{NiO}$ nanoparticles put in a volume of methylene blue aqueous solution with concentration $(10 \mathrm{ppm})$. At wavelength $(664 \mathrm{~nm})$ at different time intervals and at $\mathrm{pH}$ nearly 7 , the absorbance was measured at different time intervals using UV2 Unicam UV/Vis. Spectrometer. Adsorption capacity (mg dye/g adsorbent) of MB in the surface of nanoparticles presented. The (\%) of dye removal determined at $25{ }^{\circ} \mathrm{C}$ at different time calculated and presented.

\section{RESULTS AND DISCUSSION}

\subsection{Elemental analysis}

Lysine metal complexes are colour, soluble in both water and organic solvents. The elemental analysis (C, $\mathrm{H}, \mathrm{N}$ and $\mathrm{M}$ ) is collected in (Table 1).

Table 1.Analytical data of Lys-metal complex

\begin{tabular}{|l|l|l|l|l|l|l|l|l|l|l|}
\hline \multirow{2}{*}{ Complexes } & \multirow{2}{*}{ color } & \multirow{2}{*}{$\begin{array}{l}\text { M.P. } \\
{ }^{\circ} \mathrm{C}\end{array}$} & & \multicolumn{3}{|l|}{ \% Calculated } & \multicolumn{3}{l|}{ \%Found } \\
\cline { 5 - 12 } & & & $\mathrm{C}$ & $\mathrm{H}$ & $\mathrm{N}$ & $\mathrm{M}$ & $\mathrm{C}$ & $\mathrm{H}$ & $\mathrm{N}$ & $\mathrm{M}$ \\
\hline$\left[\mathrm{Zn}(\mathrm{Lys})_{2}\right] 6 \mathrm{H}_{2} \mathrm{O}$ & yellow & $>300$ & 31.2 & 8.1 & 12.0 & 14.0 & 30.9 & 7.5 & 11.7 & 15.0 \\
\hline$\left[\mathrm{Ni}(\mathrm{Lys})_{2}\right] 7 \mathrm{H}_{2} \mathrm{O}$ & green & $>300$ & 30.5 & 8.4 & 11.7 & 12.3 & 29.5 & 7.7 & 10.7 & 13.6 \\
\hline$\left[\mathrm{Co}(\text { Lys })_{2}\right] 7 \mathrm{H}_{2} \mathrm{O}$ & violet & $>300$ & 30.4 & 8.4 & 11.7 & 12.3 & 30.4 & 7.6 & 11.4 & 12.6 \\
\hline $\begin{array}{l}{\left[\mathrm{Cu}(\mathrm{Lys})_{2}\right] 6.5 \mathrm{H}_{2}} \\
\mathrm{O}\end{array}$ & Blue & $>300$ & 30.7 & 8.2 & 11.8 & 13.4 & 30.8 & 7.8 & 11.8 & 14.0 \\
\hline
\end{tabular}

\subsection{Infrared spectra (FT-IR)}

IR spectra of metal complexes are showed in (Figs. 1,2). Bands are collected in (Table 2). Bonding sites of complexes have been determined by comparing the spectra of metal complexes with that of Lysine. IR spectra showed shifts in bands assigned to $\delta\left(\mathrm{NH}_{2}\right)$ in range $(1630-1655) \mathrm{cm}^{-1}[15,16]$. The bands assigned to $v_{\text {as }}\left(\mathrm{COO}^{-}\right)$have been shifted to higher wavenumber as a result of their coordination to the metal ions. Also, there are shifts in bands in range $1425-1456 \mathrm{~cm}^{-1}$ which assigned to $v(\mathrm{C}-\mathrm{N})$. These results indicate that, Lysine amino acid acts as bi-dentate when coordinated to the metal ions via carboxylate oxygen and amine nitrogen group(Figs. 3). The difference between $v_{\text {as }}\left(\mathrm{COO}^{-}\right), v_{\mathrm{s}}\left(\mathrm{COO}^{-}\right)$suggests the bi-dentate nature of carboxylate.Spectra show new bands in region 500-600 and 400-500 $\mathrm{cm}^{-1}$ assigned to $v(\mathrm{M}-\mathrm{O})$ and $v(\mathrm{M}-\mathrm{N})$, respectively [17].Presence of water is confirmed by presence of broad bands in regions 3410-3482 $\mathrm{cm}^{-1}$.

Table 2.FT-IR spectral data of Lysine and its metal complexes

\begin{tabular}{|l|l|l|l|l|l|l|l|}
\hline Complexes & $v_{\text {as }}\left(\mathrm{COO}^{-}\right)$ & $v_{\mathrm{s}}\left(\mathrm{COO}^{-}\right)$ & $\delta\left(\mathrm{NH}_{2}\right)$ & $v(\mathrm{C}-\mathrm{N})$ & $(\mathrm{C}-\mathrm{O})$ & $(\mathrm{M}-\mathrm{O})$ & $(\mathrm{M}-\mathrm{N})$ \\
\hline Ligand $(\mathrm{Lys})$ & 1625 & 1382 & 1605 & 1486 & 1100 & - & - \\
\hline$\left[\mathrm{Zn}(\mathrm{Lys})_{2}\right] 6 \mathrm{H}_{2} \mathrm{O}$ & 1655 & 1368 & 1595 & 1444 & 1103 & 572 & 418 \\
\hline$\left[\mathrm{Ni}(\mathrm{Lys})_{2}\right] 7 \mathrm{H}_{2} \mathrm{O}$ & 1643 & 1374 & 1598 & 1425 & 1109 & 532 & 476 \\
\hline$\left[\mathrm{Co}(\text { Lys })_{2}\right] 7 \mathrm{H}_{2} \mathrm{O}$ & 1640 & 1363 & 1590 & 1456 & 1107 & 552 & 478 \\
\hline$\left[\mathrm{Cu}(\text { Lys })_{2}\right] 6.5 \mathrm{H}_{2} \mathrm{O}$ & 1630 & 1375 & 1590 & 1446 & 1102 & 560 & 470 \\
\hline
\end{tabular}




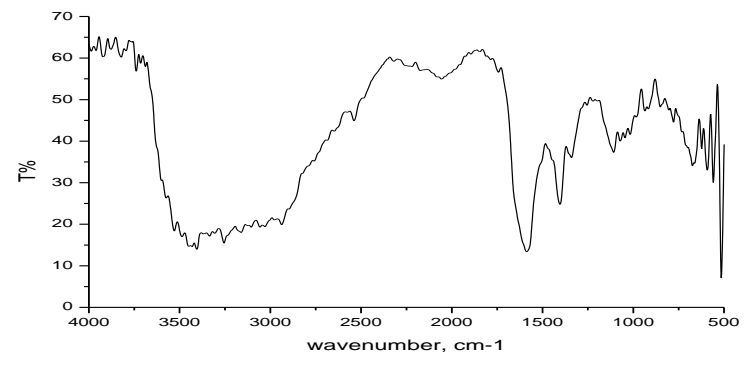

Fig. 1. IR spectrum of $\left[\mathrm{Zn}(\mathrm{Lys})_{2}\right] 6 \mathrm{H}_{2} \mathrm{Ocomplex}$

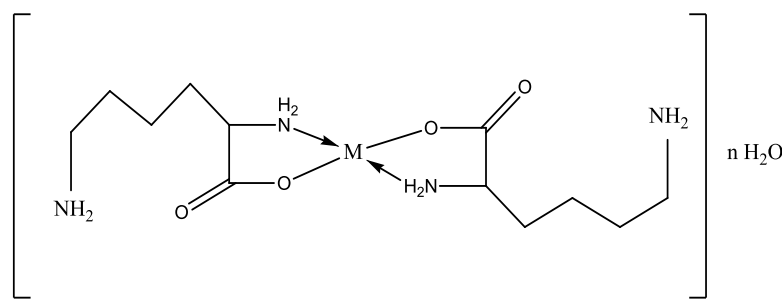



Fig. 2. IR spectrum of $\left[\mathrm{Co}(\mathrm{Lys})_{2}\right] 7 \mathrm{H} 2 \mathrm{Ocomplex}$

$\mathrm{M}=\mathrm{Zn}(\mathrm{II}) \mathrm{n}=6, \mathrm{M}=\mathrm{Cu}(\mathrm{II}) \mathrm{n}=6.5$ and $\mathrm{M}=\mathrm{Ni}(\mathrm{II}), \mathrm{Co}(\mathrm{II}) \mathrm{n}=7$

Fig. 3. Suggested structure of Lysine metal complexes

\section{3. ${ }^{1} \mathrm{H}-\mathrm{NMR}$ and ${ }^{13} \mathrm{C}$-NMR}

${ }^{1}$ H-NMR spectrum of Zinc complex(Fig. 4)showed multiplet signals in region (1.3-2.5) ppm downfield relative to TMS, assigned to protons of $\left(\mathrm{CH}_{2}\right)$ groups. The signal of $(\mathrm{CH})$ attached to $\left(\mathrm{COO}^{-}\right)$appears at 3.1 ppm and the signal of $(\mathrm{CH})$ neighboring to $\left(\mathrm{NH}_{2}\right)$. The amine protons appear as broad singlet signal at 4.7 ppm.

${ }^{13} \mathrm{C}$-NMR spectrum of Zinccomplex has been recorded in $\mathrm{d}_{6}$-DMSO (Fig. 5). The ${ }^{13} \mathrm{C}$ chemical shift of DMSO- $\mathrm{d}_{6}$ appears at (38.6) ppm [18]. The spectrum shows sharp signals represent the number of nonequivalent carbons in Lysine molecule. The signal due to the $\left(\mathrm{COO}^{-}\right)$atom appears at (176.5) $\mathrm{ppm}$. Addition signal of $(\mathrm{C}-\mathrm{N})$ appears at $(120.5) \mathrm{ppm}$. There are signal at (53.7) due to $(\mathrm{C}-\mathrm{O})$ and the signals of $\left(\mathrm{CH}_{2}\right)$ and $(\mathrm{CH})$ appears in the region (22.1-32.0) ppm.

Fig. 4. ${ }^{1} \mathrm{H}-\mathrm{NMR}$ spectrum of $\left[\mathrm{Zn}(\mathrm{Lys})_{2}\right] 6 \mathrm{H}_{2} \mathrm{O}$ complex

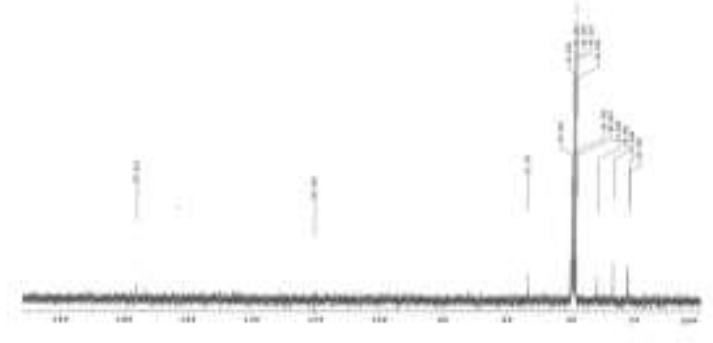

Fig. 5. ${ }^{13} \mathrm{C}-\mathrm{NMR}$ spectrum of $\left[\mathrm{Zn}(\mathrm{Lys})_{2}\right] 6 \mathrm{H}_{2} \mathrm{O}$ complex 


\subsection{Thermal analyses (TGA)}

(TGA) Thermo gravimetric analyses curves of the complexes are represented in (Figs. 6, 7) and the results are collected in (Table 3). The curves explained the role of metals on the stability of the complexes.

$\mathrm{Zn}$ (II) compound decomposed in three steps. First started from $19-120{ }^{\circ} \mathrm{C}$, corresponding to lose of three molecules of water of crystallization (Found Weight loss $10.2 \%$, Calculated Weight loss $11.6 \%$ ). The second stage represented loss of three molecules of water exist the crystal structure and not coordinate to $\mathrm{Zn}$ (II) ion [19], and $\left(\mathrm{C}_{4} \mathrm{H}_{6} \mathrm{NO}_{2}\right)$. The step lies at temperature range from $150-345^{\circ} \mathrm{C}$, (Found weight loss $28.5 \%$, Calculated Weight loss $29.9 \%$ ). The third step lied in range $346-587{ }^{\circ} \mathrm{C}$. It represents the loss of $\left(\mathrm{C}_{3} \mathrm{H}_{8} \mathrm{~N}_{3} \mathrm{O}_{2}\right.$ ), (Found weight loss $25.1 \%$, Calculated weight loss $25.3 \%$ ).

TGA curve of $\mathrm{Ni}(\mathrm{II})$ complex showed decomposition in two steps.First started from $21-120{ }^{\circ} \mathrm{C}$, corresponding to liberation of six molecules of water of crystallization, (Found Weight loss $21.5 \%$, Calculated Weight loss $22.6 \%$ ). The second stage represented the loss of one molecule of water not coordinated to metal ion but exist in the crystal structure [19], and $\mathrm{C}_{12} \mathrm{H}_{23} \mathrm{~N}_{3} \mathrm{O}_{4}$. Thestep lies in temperature range from $150-368{ }^{\circ} \mathrm{C}$ (Found Weight loss $60.4 \%$, Calculated Weight loss $61.1 \%$ ).

Thermo gravimetric analyses curve of Co(II) complex showed decomposition in three steps. The first started from $20-120{ }^{\circ} \mathrm{C}$, corresponding to liberation of three molecules of water of crystallization, (Found weight loss $11.2 \%$, Calculated weight loss $11.3 \%$ ). The second stage representes the loss of four molecules of water not coordinated to metal ion [19], and $\left(\mathrm{C}_{5} \mathrm{H}_{12} \mathrm{~N}_{2}\right)$. The step lies in temperature range from 181-399 ${ }^{\circ} \mathrm{C}$, (Found Weight loss $38.9 \%$, Calculated Weight loss $36 \%$ ). The third step lied in range $401-664{ }^{\circ} \mathrm{C}$. It represents the decomposition of the remaining complex $\left(\mathrm{CO}_{2} \mathrm{~N}_{2} \mathrm{H}_{2}\right.$ ), (Found Weight loss $14.6 \%$, Calculated Weight loss $15.9 \%)$.

Thermo gravimetric analyses curve of cupper complex showed decomposition in three steps. The first started from $44-120^{\circ} \mathrm{C}$, corresponding to decompose of two molecules of water of crystallization, (Found Weight loss $23.0 \%$, Calculated Weight loss $23.9 \%$ ). The second stage represented the loss of four and half molecules of water not coordinated to metal ion but exist in the crystal structure [19], and $\left(\mathrm{C}_{7} \mathrm{H}_{13} \mathrm{~N}_{3} \mathrm{O}_{4}\right)$. This step lies in the temperature range from $181-449{ }^{\circ} \mathrm{C}$, (Found weight loss $45.1 \%$, Calculated weight loss $44.1 \%$ ). The last step lied in range $452-800{ }^{\circ} \mathrm{C}$. It represents the loss of $\left(\mathrm{C}_{4} \mathrm{H}_{7}\right)$, (Found Weight loss 11.7 $\%$, Calculated Weight loss $11.7 \%$ ).

Table 3. Thermal analysis results of complexes

\begin{tabular}{|l|l|l|l|l|}
\hline Complexes & $\begin{array}{l}\text { TGA } \\
\text { steps }\end{array}$ & $\begin{array}{l}\text { T, }{ }^{\circ} \mathrm{C} \\
\text { range }\end{array}$ & $\begin{array}{l}\text { Wt. loss } \\
\text { found } \\
\text { (calculated })\end{array}$ & $\begin{array}{l}\text { Decomposed } \\
\text { group }\end{array}$ \\
\hline \multirow{2}{*}[\mathrm{Zn}(\text{Lys})_{2}]{$6 \mathrm{H}_{2} \mathrm{O}$} & 2 & $19-120$ & $\begin{array}{l}10.2 \\
(11.6)\end{array}$ & Loss of $3 \mathrm{H}_{2} \mathrm{O}$ \\
\cline { 2 - 5 } & 1 & $180-345$ & $\begin{array}{l}28.5 \\
(29.9)\end{array}$ & Loss of $\mathrm{C}_{4} \mathrm{H}_{6} \mathrm{NO}_{2}$ \\
\cline { 2 - 5 } & 3 & $346-587$ & $\begin{array}{l}25.1 \\
(25.3)\end{array}$ & Loss of $\mathrm{C}_{3} \mathrm{H}_{8} \mathrm{~N}_{3} \mathrm{O}_{2}$ \\
\hline$\left[\mathrm{Ni}(\mathrm{Lys})_{2}\right] 7 \mathrm{H}_{2} \mathrm{O}$ & 1 & $21-120$ & $\begin{array}{l}21.5 \\
(22.6)\end{array}$ & Loss of $6 \mathrm{H}_{2} \mathrm{O}$ \\
\cline { 2 - 5 } & 2 & $180-368$ & $\begin{array}{l}60.4 \\
(61.1)\end{array}$ & $\begin{array}{l}\text { Loss of } \\
\mathrm{C}_{12} \mathrm{H}_{23} \mathrm{~N}_{3} \mathrm{O}\end{array}$ \\
\hline$\left[\mathrm{Co}(\mathrm{Lys})_{2}\right] 7 \mathrm{H}_{2} \mathrm{O}$ & 1 & $20-120$ & 11.2 & Loss of $3 \mathrm{H}_{2} \mathrm{O}$ \\
\hline
\end{tabular}




\begin{tabular}{|l|l|l|l|l|}
\hline & & & $(11.3)$ & \\
\cline { 2 - 5 } & 2 & $180-399$ & $\begin{array}{l}38.9 \\
(36.0)\end{array}$ & $\begin{array}{l}\text { Loss of } 3 \mathrm{H}_{2} \mathrm{O} \text { and } \\
\mathrm{C}_{5} \mathrm{H}_{12} \mathrm{~N}_{2}\end{array}$ \\
\cline { 2 - 5 }$\left[\mathrm{Cu}(\text { Lys })_{2}\right] 6.5 \mathrm{H}_{2} \mathrm{O}$ & 2 & $401-664$ & $\begin{array}{l}14.6 \\
(15.9)\end{array}$ & Loss of $\mathrm{CO}_{2} \mathrm{~N}_{2} \mathrm{H}_{2}$ \\
\cline { 2 - 5 } & 1 & $44-120$ & $\begin{array}{l}23.0 \\
(23.9)\end{array}$ & Loss of $6.5 \mathrm{H}_{2} \mathrm{O}$ \\
\cline { 2 - 5 } & 2 & $180-449$ & $\begin{array}{l}45.1 \\
(44.1)\end{array}$ & $\begin{array}{l}\text { Loss } \\
\mathrm{C}_{7} \mathrm{H}_{13} \mathrm{~N}_{3} \mathrm{O}_{4}\end{array}$ \\
\cline { 2 - 5 } & 3 & $452-800$ & $\begin{array}{l}11.7 \\
(11.7)\end{array}$ & Loss of $\mathrm{C}_{4} \mathrm{H}_{7}$ \\
\hline
\end{tabular}

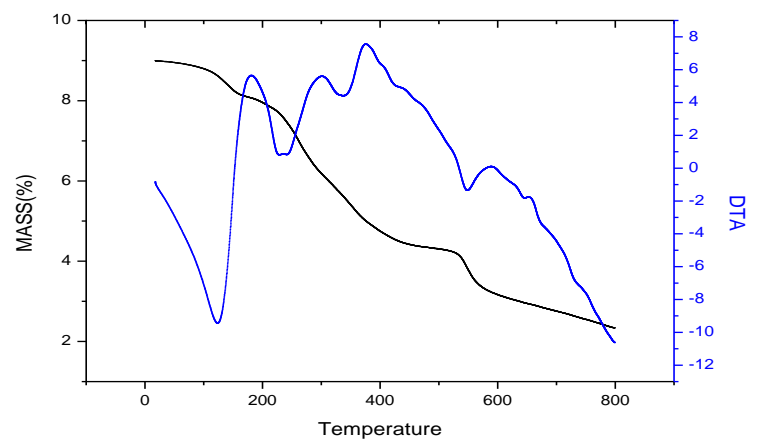

Fig. 6. TGA-DTA curves of $\left[\mathrm{Zn}(\mathrm{Lys})_{2}\right] 6 \mathrm{H}_{2} \mathrm{O}$ complex

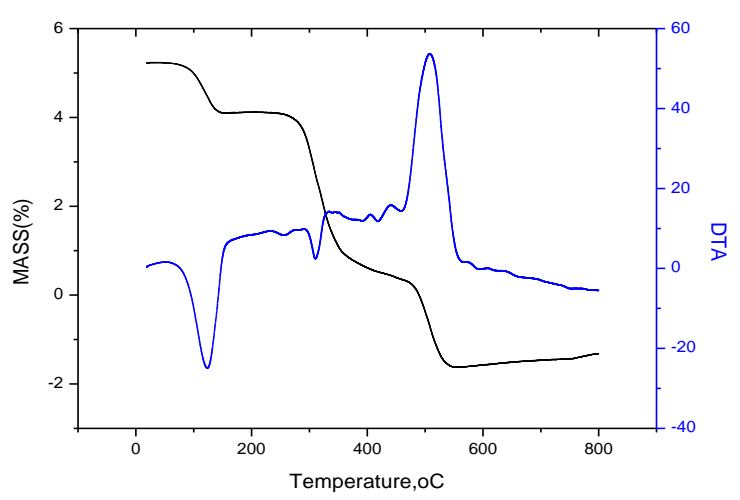

Fig. 7. TGA-DTA curves of $\left[\mathrm{Ni}(\text { Lys })_{2}\right] 7 \mathrm{H}_{2} \mathrm{O}$ complex

By applying Coats- Redfern (CR) and Horowitz-Metzger (HM) equations[20, 21],thermodynamic parameters $\left(\mathrm{E}^{*}, \Delta \mathrm{H}^{*}, \Delta \mathrm{G}^{*}, \Delta \mathrm{S}^{*}\right)$ have been calculated and presented in (Table 4). The negative entropy $\left(\Delta \mathrm{S}^{*}\right)$ values indicate that, structure of complexes is high ordered than that of decomposition products. $\mathrm{E}^{*}$ was determined graphically (Figs. 8, 9). The highest activation energies are reported for $\mathrm{Ni}$ (II) compex, reflecting the strong bonding between $\mathrm{Ni}$ (II) ion and the ligand. The positive values of all the steps in all the complexes indicate the endothermic nature of the decomposition steps. On the other hand, the positive values of all decomposition steps confirm the non-spontaneous nature of the decomposition processes.

Table 4. Thermodynamic parameters of complexes

\begin{tabular}{|l|l|l|l|l|l|}
\hline \multirow{2}{*}{ Complexes } & $\begin{array}{l}\mathrm{TGA} \\
\text { steps }\end{array}$ & $\begin{array}{l}\mathrm{E}^{*} \\
\mathrm{KJ} \mathrm{mol}^{-1}\end{array}$ & $\begin{array}{l}\Delta \mathrm{S}^{*} \\
\mathrm{JK}^{-1} \mathrm{~mol}^{-1}\end{array}$ & $\begin{array}{l}\Delta \mathrm{H}^{*} \\
\mathrm{KJ} \mathrm{mol}^{-1}\end{array}$ & $\begin{array}{l}\Delta \mathrm{G}^{*} \\
\mathrm{KJ} \mathrm{mol}^{-1}\end{array}$ \\
\hline \multirow{2}{*}[\mathrm{Zn}(\mathrm{Lys})_{2}]{$6 \mathrm{H}_{2} \mathrm{O}$} & 1 & 5.57 & -283.27 & 3.09 & 102.42 \\
\cline { 2 - 7 } & 2 & 1.45 & -259.8 & 4.45 & 134.8 \\
\cline { 2 - 7 } & 3 & 6.01 & -301.39 & 6.14 & 216.73 \\
\hline
\end{tabular}




\begin{tabular}{|l|l|l|l|l|l|}
\hline \multirow{2}{*}{ Total } & - & 13.03 & -844.46 & 13.68 & 453.95 \\
\hline \multirow{2}{*}[\mathrm{Ni}(\mathrm{Lys})_{2}]{$7 \mathrm{H}_{2} \mathrm{O}$} & 1 & 8.13 & -310.13 & 3.10 & 112.73 \\
\cline { 2 - 6 } & 2 & 1.254 & -294.32 & 4.55 & 156.59 \\
\hline \multirow{2}{*}[\mathrm{Cotal}(\mathrm{Lys})_{2}]{$7 \mathrm{H}_{2} \mathrm{O}$} & - & 49.39 & -604.45 & 7.65 & 269.32 \\
\hline \multirow{2}{*}{ Total } & 1 & 6.49 & -295.70 & 3.10 & 107.19 \\
\cline { 2 - 7 } & 3 & 1.52 & -255.55 & 4.68 & 139.19 \\
\hline \multirow{3}{*}[\mathrm{Cu}(\mathrm{Lys})_{2}]{$6.5 \mathrm{H}_{2} \mathrm{O}$} & - & 4.20 & -313.75 & 6.69 & 246.03 \\
\cline { 2 - 7 } & 2 & 12.21 & -865.00 & 14.47 & 492.41 \\
\cline { 2 - 7 } & 3 & 2.63 & -324.75 & 3.20 & 121.82 \\
\hline Total & - & 1.02 & -303.02 & 4.88 & 173.28 \\
\hline
\end{tabular}



Fig. 8. Graphical determination of $E^{*}$ for $\left[\mathrm{Zn}(\mathrm{Lys})_{2}\right] 6 \mathrm{H}_{2} \mathrm{O}$ complex

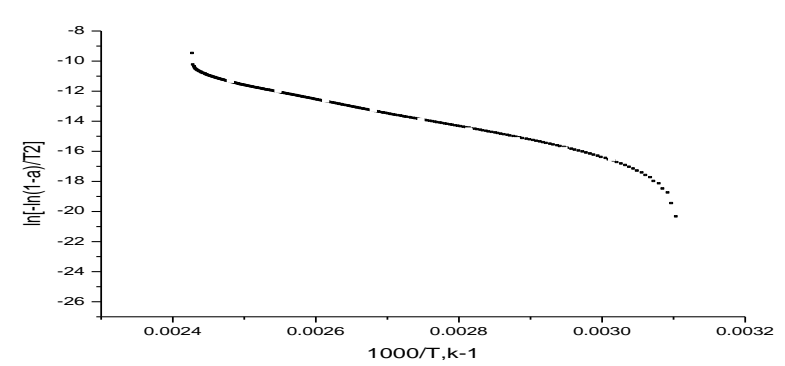

Fig. 9. Graphical determination of $E^{*}$ $\left[\mathrm{Ni}(\mathrm{Lys})_{2}\right] 7 \mathrm{H}_{2} \mathrm{O}$ complex

\subsection{Electron Spin Resonance (ESR) of $\mathrm{Cu}(\mathrm{II})$ complex}

ESR spectra of cupper complex (Fig. 10)has been recorded in solid state at $25^{\circ} \mathrm{C}$. The g-tensor value of cupper complex $\left(\mathrm{g}_{\|}=2.15591, \mathrm{~g}_{\perp}=2.0498\right)$ confirm the presence of square planar geometry, the unpaired electron lies in $\mathrm{dx}^{2}-\mathrm{y}^{2}$ orbital giving ${ }^{2} \mathrm{~B}_{1 \mathrm{~g}}$ as the ground state with $\mathrm{g}_{\|}>\mathrm{g}_{\perp}>2$ [22]. Axial symmetry parameter (G) was found to be (3.1).

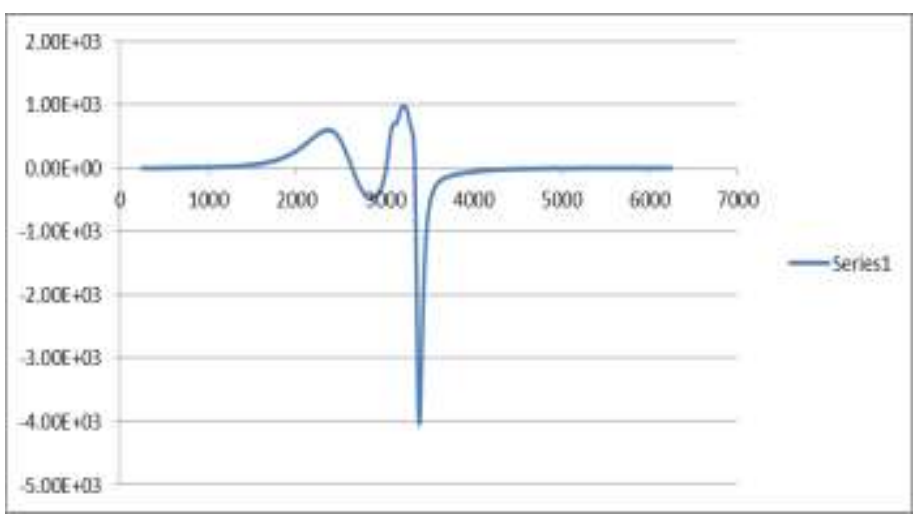

Fig. 10. Electron Spin Resonance of $\left[\mathrm{Cu}(\mathrm{Lys})_{2}\right] 6.5 \mathrm{H}_{2} \mathrm{Ocomplex}$ 


\subsection{Electronic spectra and magnetic moments $\left(\mu_{\mathrm{eff}}\right)$}

Spectrum of Ni(II) compound in DMF showed a broad band at $27322 \mathrm{~cm}^{-1}$, which assigned to (LMCT) and bands centared at $16339 \mathrm{~cm}^{-1}$ and $14891 \mathrm{~cm}^{-1}$ which assigned to ${ }^{3} \mathrm{~T}_{1} \rightarrow{ }^{3} \mathrm{~T}_{1}(\mathrm{P})$ and ${ }^{3} \mathrm{~T}_{1} \rightarrow{ }^{1} \mathrm{E}$ as forbidden transition, respectively. The spectrum suggests tetrahedral geometry [23].Magnetic moment is (3.6 B.M).

UV-visible spectrum of $\mathrm{Co}$ (II) showed a band at $16528 \mathrm{~cm}^{-1}$, which assigned to ${ }^{4} \mathrm{~A}_{2} \rightarrow{ }^{4} \mathrm{~T}_{1}(\mathrm{P})$ and a band at $27027 \mathrm{~cm}^{-1}$, which assigned to (LMCT). Spectrum suggests tetrahedral geometry around Co(II) [24]. Magnetic moment value was (4.5 B.M).

Spectrum of $\mathrm{Cu}$ (II) appeared a band at regian $26315 \mathrm{~cm}^{-1}$, which assigned to (LMCT) and a band located at $14947 \mathrm{~cm}^{-1}$ and $16233 \mathrm{~cm}^{-1}$, which assigned to $\left({ }^{2} \mathrm{~B}_{1 \mathrm{~g}} \rightarrow{ }^{2} \mathrm{E}_{1 \mathrm{~g}}\right)$ and $\left({ }^{2} \mathrm{~B}_{1 \mathrm{~g}} \rightarrow{ }^{2} \mathrm{~A}_{1}\right)$ transition, respectively. The spectrum suggests square-planar geometry [25]. Magnetic moment of copper complex was (2.1 B.M) [25].The electronic spectra are represented in (Figs. 11, 12) and(Table 5), respectively.

Table 5. Electronic bands and magnetic moments $\left(\mu_{\text {eff }}\right)$ of Lysine metal complexes

\begin{tabular}{|c|c|c|}
\hline Complexes & Bands Position, $\mathrm{cm}^{-1}$ & $\begin{array}{c}\text { Magnetic Moments } \\
\left(\mu_{\text {eff }}\right)\end{array}$ \\
\hline$\left[\mathrm{Ni}(\text { Lys })_{2}\right] 7 \mathrm{H}_{2} \mathrm{O}$ & 27322 & 3.6 B.M. \\
& 16339 & \\
\hline$\left[\mathrm{Co}(\mathrm{Lys})_{2}\right] 7 \mathrm{H}_{2} \mathrm{O}$ & 14891 & 4.5 B.M. \\
& 27027 & \\
\hline$\left[\mathrm{Cu}(\mathrm{Lys})_{2}\right] 6.5 \mathrm{H}_{2} \mathrm{O}$ & 16528 & 2.1 B.M. \\
& 14992 & \\
\hline
\end{tabular}

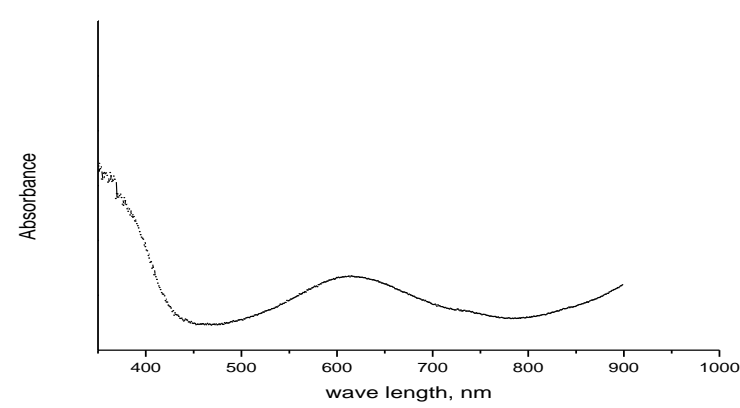

Fig. 11. Electronic spectrum of $\left[\mathrm{Ni}(\mathrm{Lys})_{2}\right] 7 \mathrm{H}_{2} \mathrm{O}$ complex

\subsection{X-Ray Powder Diffraction (XRD)}

$\mathrm{Ni}$ (II) complex was used as precursor of nicle oxide nanoparticles by decomposition at 800 ${ }^{\circ}$ C.(Fig. 13) showed XRD powder diffraction pattern of $\mathrm{NiO}$ after calcining the precursor of $\mathrm{Ni}$ (II) complex at $800{ }^{\circ} \mathrm{C}$. The peaks are well indexed to $\mathrm{NiO}$ with monoclinc crystal structures

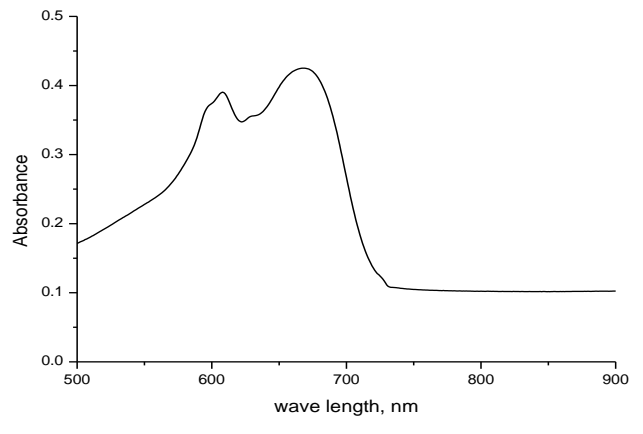

Fig. 12. Electronic spectrum of $\left[\mathrm{Co}(\mathrm{Lys})_{2}\right] 7 \mathrm{H}_{2} \mathrm{O}$ complex

with lattice parameters $\mathrm{a}=4.692 \AA$, $\mathrm{b}=3.428 \AA$ and $\mathrm{c}=5.136 \AA$. Where $2 \theta=35.72$, $43.26,62.89,75.38$ and 79.35 attributed to the planes (111), (200), (220), (311) and (222), respectively of NiO nanoparticle (JCPDS 01-0721464). The crystallite size of nickel oxide was determined using Debye-Scherrer formula $\mathrm{D}=$ $0.89 \lambda / \beta \cos \theta$. Where $\lambda=$ wavelength of $\mathrm{x}$-ray $(1.5406 \AA$ ) for $\mathrm{Cu} \mathrm{K} \alpha$ radiation, $\beta$ is full 
width at half maximum and $\theta$ is the peak position. The crystallite size was found to be $45 \mathrm{~nm}$.

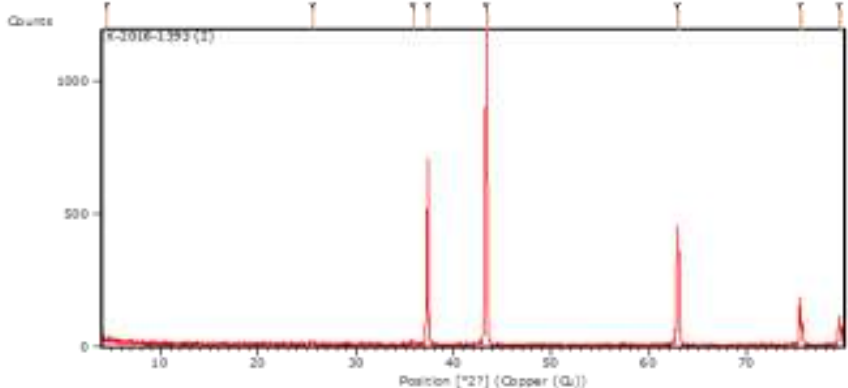

Fig. 13. XRD pattern of $\mathrm{NiO}$ nanoparticles

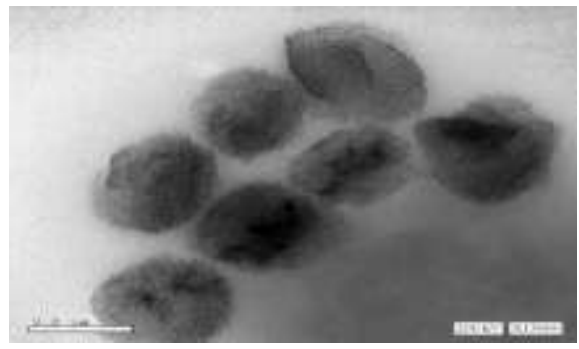

Fig. 14. TEM image of $\mathrm{NiO}$ nanoparticles

\section{8. (HR-TEM)}

TEM images of NiO nano-crystals (Fig. 14) showed the average particle size 43-52 $\mathrm{nm}$. This value agrees with that obtained from XRD results

\subsection{Solubility and density measurements}

Molal solubility (molality) and density in (ethanol-water) mixed solvent with ethanol different mole fractions $\left(x_{I}=(0.00-1.00)\right.$ at $25{ }^{\circ} \mathrm{C}$ were measured. The values of solubility and density of complexes are represented in (Table 6).

The data showed that, solubility of complexes decrease as the mole fraction of ethanol increase. This explained that, the solvation process of complexes decrease as the mole fraction of ethanol increase. The results showed that, the density of complexes is slightly decreased as the mole fraction of ethanol increase. Thus, the solvated volume of complexes decrease as the mole fraction increase.

Table 6. Molality (m) and Density $(\rho)$ of complexes in ethanol-water mixed solvent with different mole fractions of ethanol $\left(x_{l}=(0.00-1.00)\right.$ at $25^{\circ} \mathrm{C}$

\begin{tabular}{|l|l|l|l|l|l|l|l|l|}
\hline \multirow{2}{*}{$\mathrm{x}_{1}$} & \multicolumn{6}{l}{$\mathrm{m}(\mathrm{mol} / \mathrm{kg}$ solvent $)$} & \multicolumn{2}{l|}{$\rho\left(\mathrm{g} / \mathrm{cm}^{3}\right)$} \\
\cline { 2 - 9 } & Lys-Zn & Lys-Ni & Lys-Co & Lys-Cu & Lys-Zn & Lys-Ni & Lys-Co & Lys-Cu \\
\hline 0.000 & 0.019 & 0.044 & 0.185 & 0.005 & 1.0273 & 1.2488 & 1.0378 & 1.2563 \\
\hline 0.071 & 0.009 & 0.043 & 0.016 & 0.002 & 1.0088 & 1.1789 & 1.0340 & 1.1839 \\
\hline 0.170 & 0.008 & 0.042 & 0.013 & 0.002 & 0.9623 & 1.1392 & 0.9503 & 1.1639 \\
\hline 0.315 & 0.002 & 0.030 & 0.007 & 0.001 & 0.9044 & 1.1023 & 0.9426 & 1.1494 \\
\hline 0.551 & 0.002 & 0.008 & 0.003 & 0.001 & 0.8167 & 1.0511 & 0.9029 & 1.0668 \\
\hline 1.000 & 0.001 & 0.001 & 0.0002 & 0.0002 & 0.7741 & 0.9620 & 0.8205 & 1.0068 \\
\hline
\end{tabular}

The solubility of complexes in (ethanol-water) of ethanol different mole fractionssolvent in range (0.001.00) was analyzed in term ofSetchenow relationship [26], as in the following equation:

$$
\log _{10}\left(\mathrm{~S}_{\mathrm{o}} / \mathrm{S}\right)=\mathrm{k} x_{1}
$$

Where $S_{0}$ and $S$ is the solubility of complexes in water in absence and in presence of ethanol solvent respectively, $x_{1}$ ismole fraction of ethanol solvent. Examination of plots in present study for complexes in water and in presence of ethanol different mole fraction, resulting in extended Setchenow relation:

$$
\log _{10}(\mathrm{~S} / \mathrm{S})=k_{\circ}+k_{l}\left(x_{1}\right)
$$

The Setchenow coefficients (activity constants); $\mathrm{k}_{\circ}$ and $\mathrm{k}_{1}$ were reported in (Table 7). 
Table 7. Setchenowcoeffient, $\mathrm{k}$ and $\mathrm{k}_{1}$ of the complexes in presence of different mole fractions of ethanol solvent at $25{ }^{\circ} \mathrm{C}$

\begin{tabular}{|l|l|l|l|l|}
\hline Coeffient & Lys-Zn & Lys-Ni & Lys-Co & Lys-Cu \\
\hline $\mathrm{k}_{\circ}$ & 0.2654 & 0.2595 & 0.2118 & 0.228 \\
\hline $\mathrm{k}_{1}$ & 1.0088 & 1.2049 & 1.0224 & 1.2179 \\
\hline
\end{tabular}

From result of Setchenow coffins ( $\mathrm{k}$ - and $\mathrm{k}_{1}$ value), the effect of ethanol mole fraction on solubility of complexes was in order: $\mathrm{Zn}(\mathrm{II})>\mathrm{Ni}(\mathrm{II})>\mathrm{Cu}(\mathrm{II})>\mathrm{Co}$ (II). This indicates decrease in the solvation process of the complexes in the same order as the mole fraction of ethanol solvent increase.

\subsection{Apparent molal volume calculations}

From the molal solubility (molality) and density data of complexes in (ethanol-water) mixed solvent with ethanol different mole fractions $\left(x_{I}=(0.00-1.00)\right.$ at $25{ }^{\circ} \mathrm{C}$, apparent molal volume $\left(\mathrm{V}_{\mathrm{Q}}\right)$, Wander Walls volume $\left(\mathrm{V}_{\mathrm{W}}\right)$, electrostriction volume $\left(\mathrm{V}_{\mathrm{e}}\right)$ and solvated radius $(\mathrm{r})$ were calculated.Apparent molal volume $\left(\mathrm{V}_{\mathrm{Q}}\right)$ was calculated using the following relation[27]:-

$$
\mathrm{V}_{\mathrm{Q}}=\frac{M}{\rho}-\frac{1000}{\mathrm{~m}}\left[\frac{1}{\rho^{*}}-\frac{1}{\rho}\right]
$$

Where $\mathrm{M}=$ molecular weight of complexes, $m=$ molal concentration of complexes in solution; $\rho^{\circ}$ and $\rho$ are densities of solvent andsolution, respectively. Apparent molal volume of the complexes is increase as ethanolmole fraction increase, due to the decrease of solution density in the same direction, where the volume has inverse proportion change with density.

The solvated radii of complexes can be calculated as the following equation.

$$
\mathrm{V}_{\mathrm{Q}}=\frac{4}{3} \pi r^{3}
$$

The packing density is found to be constant $[28,29]$.Therefore the Van der Waals volumes $\left(\mathrm{V}_{\mathrm{w}}\right)$ of the complexes can be calculated by apply the following equation [29].

$$
\text { Packing density }(\mathrm{P})=V_{w} / V \varphi=0.661 \pm 0.017
$$

The electrostriction volume $\left(V_{e}\right)$ [28-31],can be calculated using the following equation.

$$
V_{e}=V_{w}-\varphi V
$$

The calculated values of $\left(\mathrm{V}_{\mathrm{Q}}\right),\left(\mathrm{V}_{\mathrm{w}}\right),\left(V_{e}\right)$ and the solvated radius of complexes are recorded in (Tables 8,9$)$.

Table 8. Apparent molal volume $\left(\mathrm{V}_{\mathrm{Q}}\right)$ and solvated radius $(\mathrm{r})$ of complexes in (ethanol-water) mixed solvent with different mole fractions of ethanol $\left(x_{I}=(0.00-1.00)\right.$ at $25^{\circ} \mathrm{C}$

\begin{tabular}{|l|l|l|l|l|l|l|l|l|}
\hline \multirow{2}{*}{$\mathrm{x}_{1}$} & \multicolumn{4}{|c|}{$\mathrm{V}_{\mathrm{Q}}\left(\mathrm{cm}^{3} / \mathrm{mol}\right)$} & \multicolumn{4}{c|}{$\mathrm{r}(\mathrm{cm})$} \\
\cline { 2 - 9 } & Lys-Zn & Lys-Ni & Lys-Co & Lys-Cu & Lys-Zn & Lys-Ni & Lys-Co & Lys-Cu \\
\hline 0.000 & 450.98 & 394.44 & 458.00 & 367.38 & 4.75 & 4.55 & 4.78 & 4.44 \\
\hline 0.071 & 459.25 & 417.83 & 459.69 & 389.85 & 4.78 & 4.63 & 4.78 & 4.53 \\
\hline 0.170 & 481.45 & 432.39 & 500.18 & 396.55 & 4.86 & 4.69 & 4.92 & 4.55 \\
\hline 0.315 & 512.27 & 446.87 & 504.27 & 401.55 & 4.96 & 4.74 & 4.93 & 4.57 \\
\hline 0.551 & 567.28 & 468.64 & 526.44 & 432.64 & 5.13 & 4.81 & 5.00 & 4.69 \\
\hline 1.000 & 598.50 & 512.05 & 579.31 & 458.43 & 5.22 & 4.96 & 5.17 & 4.78 \\
\hline
\end{tabular}


Table 9. Vander Wall Volume $\left(\mathrm{V}_{\mathrm{W}}\right)$ and electrostriction volume $\left(\mathrm{V}_{\mathrm{e}}\right)$ of complexes in (ethanol-water) mixed solvent with different mole fractions of ethanol $\left(x_{I}=(0.00-1.00)\right.$ at $25^{\circ} \mathrm{C}$

\begin{tabular}{|l|l|l|l|l|l|l|l|l|}
\hline \multirow{2}{*}{$\mathrm{x}_{1}$} & \multicolumn{9}{|l|}{$\mathrm{V}_{\mathrm{W}}\left(\mathrm{cm}^{3} / \mathrm{mol}\right)$} & \multicolumn{2}{l|}{$\mathrm{Ve}\left(\mathrm{cm}^{3} / \mathrm{mol}\right)$} \\
\cline { 2 - 9 } & Lys-Zn & Lys-Ni & Lys-Co & Lys-Cu & Lys-Zn & Lys-Ni & Lys-Co & Lys-Cu \\
\hline 0.000 & 395.60 & 338.47 & 382.92 & 303.02 & 55.37 & 55.97 & 75.08 & 64.36 \\
\hline 0.071 & 303.56 & 276.18 & 303.86 & 257.69 & 155.68 & 141.64 & 155.83 & 132.16 \\
\hline 0.170 & 318.23 & 285.81 & 330.62 & 262.12 & 163.21 & 146.58 & 169.56 & 134.43 \\
\hline 0.315 & 338.61 & 295.38 & 333.32 & 265.42 & 173.66 & 151.49 & 170.94 & 136.12 \\
\hline 0.551 & 374.97 & 309.77 & 347.98 & 285.98 & 192.30 & 158.87 & 178.46 & 146.66 \\
\hline 1.000 & 395.60 & 338.47 & 382.92 & 303.02 & 202.89 & 173.58 & 196.38 & 155.40 \\
\hline
\end{tabular}

\subsection{Refractive index measurements}

Refractive indices of complexes in (ethanol-water) mixed solvent with ethanol different mole fractions $\left(x_{I}=\right.$ $(0.00-1.00)$ at $25{ }^{\circ} \mathrm{C}$ were measured. The values of refractive indices of complexes are recorded in (Table 10). Excess refractive indices $\left(n^{E}\right)$ in presence of complexes in (ethanol-water) solutions were calculated according to following equation and listed in (Table 10) and represented in (Fig. 15).

$$
\mathrm{n}^{\mathrm{E}}=(\mathrm{n})-\left(\mathrm{x}_{1} \mathrm{n}_{1}+\mathrm{x}_{2} \mathrm{n}_{2}\right)
$$

Where $n=$ refractive index of complex in mixed (ethanol-water) solvents, $n_{l}=$ refractive index of complexes in pure ethanol solvent and $n_{2}$ is the refractive index of the complex in pure water. The results show moderate change in refractive indicates values of complexes solution thanrefractive indicates of pure solvent [32]. This indicates moderate solvation process with respect to this property. Excess refractive indices $\left(n^{E}\right)$ reach a maximum value at ethanol mole fraction (0.315) for all complexes. This indicates higher solvation of complexes at mole fraction (0.315) of ethanol in (ethanol-water) mixed solvents.

From values of refractive indices, complexes in (ethanol-water) mixed solvent with ethanol mole fraction of (0.00-1.00) at $25^{\circ} \mathrm{C}$, molar refraction $\left(R_{m}\right)$ can be calculated [33],from following equation:

$$
R_{m}=\frac{n^{2}-1}{n^{2}+2} \mathrm{~V}_{\mathrm{Q}}=\mathrm{P}_{\mathrm{A}}+\mathrm{P}_{\mathrm{E}}=\mathrm{P}_{\mathrm{D}}+\mathrm{P}_{\mathrm{T}}
$$

Where, $\mathrm{V}_{\mathrm{Q}}$ and $n$ were the apparent molal volume and the refractive index of complexes in solution, respectively

The atomic polarization $\left(\mathrm{P}_{\mathrm{A}}\right)$ can be calculated [34], from following relation:

$$
P_{A}=1.05 n^{2}
$$

From the optical refractive index $(n)$ of a material containing $N$ molecules per unit volume, the mean value of the molecular dipole polarizability $(\alpha)$ can be calculatedby applying Lorenz-Lorenz formulaas shown in the following equation:

$$
\frac{n^{2}-1}{n^{2}+2}=\frac{4 \pi \hat{n} \alpha}{3}
$$

Where, $\hat{n}=\frac{N}{\varphi V},(\mathrm{~N})$ is the Avogadro's number and $(\varphi \mathrm{V})$ is the apparent molal volume.

The values of atomic polarization $\left(\mathrm{P}_{\mathrm{A}}\right)$, molar refraction $\left(R_{m}\right)$ and polarizability $(\alpha)$ were recorded in (Tables 11 and 12). 
The molar refraction and polarizability are directly proportional to apparent molal volume. Molar refraction and polarizability in (ethanol-water) mixed solvent with ethanol mole fractions of (0.00-1.00) at $25^{\circ} \mathrm{C}$, is increase asmole fraction of ethanol increase. This increase in molar refraction and polarizability of complexes with mole fraction of ethanol may be related to increase in apparent molar volume with mole fraction of ethanol, respectively.

Table 10. Refractive indices of pure solvent, complexesand excess refractive indices $\left(\mathrm{n}^{\mathrm{E}}\right)$ in (ethanol-water) mixed solvent with different mole fractions of ethanol $\left(x_{l}=(0.00-1.00)\right.$ at $25^{\circ} \mathrm{C}$

\begin{tabular}{|c|c|c|c|c|c|c|c|c|c|}
\hline \multirow[b]{2}{*}{$x_{1}$} & \multirow[t]{2}{*}{$\mathrm{n}_{\mathrm{D} \text { solvent }}$} & \multicolumn{4}{|l|}{$\mathrm{n}_{\mathrm{D} \text { solution }}$} & \multicolumn{4}{|l|}{$\mathrm{n}^{\mathrm{E}}$} \\
\hline & & Lys-Zn & Lys-Ni & Lys-Co & Lys-Cu & $\begin{array}{l}\text { Lys- } \\
\mathrm{Zn}\end{array}$ & $\begin{array}{l}\text { Lys- } \\
\mathrm{Ni}\end{array}$ & Lys-Co & Lys-Cu \\
\hline 0.000 & 1.3345 & 1.3382 & 1.3374 & 1.3362 & 1.3350 & 0.000 & 0.000 & 0.0000 & 0.0000 \\
\hline 0.071 & 1.3451 & 1.3457 & 1.3479 & 1.3461 & 1.3469 & 0.005 & 0.008 & 0.0078 & 0.0089 \\
\hline 0.170 & 1.3545 & 1.3572 & 1.3589 & 1.3570 & 1.3571 & 0.014 & 0.016 & 0.0159 & 0.0170 \\
\hline 0.315 & 1.3620 & 1.3630 & 1.3633 & 1.3639 & 1.3635 & 0.020 & 0.017 & 0.0175 & 0.0188 \\
\hline 0.551 & 1.3655 & 1.3655 & 1.3655 & 1.3665 & 1.3662 & 0.010 & 0.012 & 0.0134 & 0.0144 \\
\hline 1.000 & 1.3640 & 1.3660 & 1.3650 & 1.3665 & 1.3649 & 0.000 & 0.00 & 0.000 & 0.00 \\
\hline
\end{tabular}

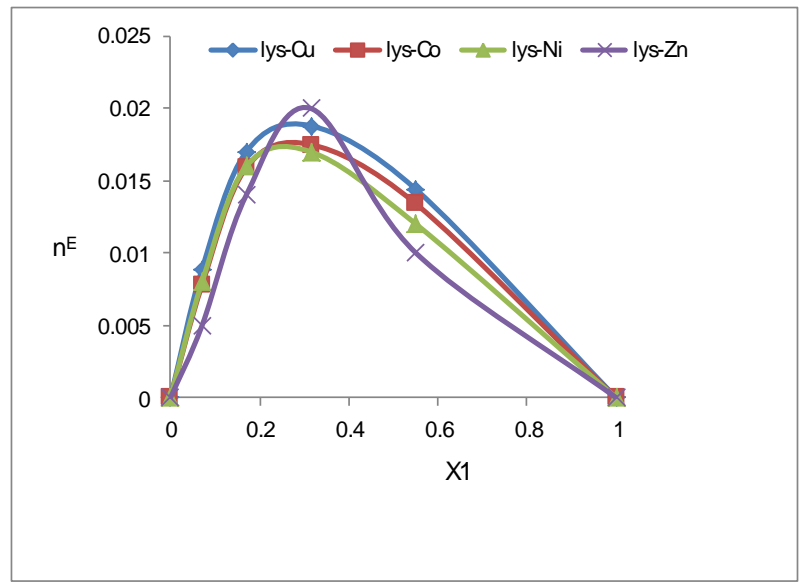

Fig. 15. Excess refractive indices of complexes as a function of the mole fraction of ethanol $\left(x_{1}\right)$ at $25{ }^{\circ} \mathrm{C}$

Table 11. Atomic polarization $\left(\mathrm{P}_{\mathrm{A}}\right)$ of the complexes in (ethanol-water) mixed solvent with different mole fractions of ethanol at $25{ }^{\circ} \mathrm{C}$

\begin{tabular}{|l|l|l|l|l|}
\hline \multirow{2}{*}{$\mathrm{x}_{1}$} & \multicolumn{4}{|l|}{$\mathrm{P}_{\mathrm{A}}$} \\
\cline { 2 - 5 } & Lys-Zn & Lys-Ni & Lys-Co & Lys-Cu \\
\hline 0.000 & 1.881 & 1.878 & 1.874 & 1.871 \\
\hline 0.071 & 1.902 & 1.907 & 1.902 & 1.904 \\
\hline 0.170 & 1.935 & 1.938 & 1.933 & 1.933 \\
\hline 0.315 & 1.951 & 1.951 & 1.953 & 1.952 \\
\hline 0.551 & 1.958 & 1.957 & 1.960 & 1.959 \\
\hline 1.000 & 1.959 & 1.956 & 1.960 & 1.956 \\
\hline
\end{tabular}


Table 12. Molar refraction $\left(\mathrm{R}_{\mathrm{m}}\right)$ and Polarizability $(\alpha)$ of the complexes in (ethanol-water) mixed solvent with different mole fractions of ethanol at $25^{\circ} \mathrm{C}$

\begin{tabular}{|l|l|l|l|l|l|l|l|l|}
\hline \multirow{2}{*}{$\mathrm{x}_{1}$} & \multicolumn{4}{|l}{ Molar refraction $\mathrm{R}_{\mathrm{m}}\left(\mathrm{cm}^{3} / \mathrm{mol}\right)$} & \multicolumn{3}{l|}{ Polarizability $\left(\alpha \times 10^{-23}\right)$} & $\left(\mathrm{cm}^{3} / \mathrm{molecule}\right)$ \\
\cline { 2 - 10 } & Lys-Zn & Lys-Zn & Lys-Ni & Lys-Co & Lys-Zn & Lys-Ni & Lys-Co & Lys-Cu \\
\hline 0.000 & 94.070 & 82.100 & 95.030 & 75.981 & 3.730 & 3.255 & 3.768 & 3.012 \\
\hline 0.071 & 97.720 & 89.420 & 97.910 & 83.215 & 3.874 & 3.545 & 3.882 & 3.299 \\
\hline 0.170 & 105.51 & 95.160 & 109.56 & 86.884 & 4.183 & 3.773 & 4.344 & 3.445 \\
\hline 0.315 & 113.90 & 99.430 & 112.37 & 89.395 & 4.516 & 3.942 & 4.455 & 3.544 \\
\hline 0.551 & 126.91 & 104.84 & 118.06 & 96.958 & 5.032 & 4.157 & 4.681 & 3.844 \\
\hline 1.000 & 134.06 & 114.41 & 129.92 & 102.41 & 5.315 & 4.536 & 5.151 & 4.060 \\
\hline
\end{tabular}

\subsection{Effect of solvent on UV-visible spectra}

UV-visible spectra of complexes in (ethanol-water) mixed solvent with ethanol different mole fractions $\left(x_{l}=\right.$ $(0.00,0.235$ and 1.00$)$ at $25^{\circ} \mathrm{C}$ were measured at $25^{\circ} \mathrm{C}$ and represented in (Figs. 16) as example. The values of both the wavelength and the absorbance of complexes are collected in (Table13).

Inspection of the data in (Table 13) one can note that, there is an increase in wavelength in transferring from $0 \%$ to $100 \%$ (ethanol-water) mixtures, i.e. blue shift takes place. Also, the results show that there is decrease or increase in the absorbance in transferring from $0 \%$ to $100 \%$ (ethanol-water) mixtures, i.e. hypochromic or hyper chromic effect.

Table 13. UV-spectra data of complexes in (ethanol-water) mixed solvent with different mole fractions of ethanol $\left(x_{1}\right)$ at $25^{\circ} \mathrm{C}$

\begin{tabular}{|c|c|c|c|c|c|c|}
\hline$x$ & 0.000 & & 0.235 & & 1.000 & \\
\hline comple & $\lambda, \mathrm{nm}$ & A & $\lambda, \mathrm{nm}$ & A & $\lambda, \mathrm{nm}$ & A \\
\hline Lys-Zn & 340 & 0.243 & 400 & 0.211 & No beak & No beak \\
\hline $\mathrm{I}$ & 617 & 0007 & 373 & 0.079 & 620 & 0230 \\
\hline Lys-1NI & 017 & 0.001 & 525 & 0.045 & $0<0$ & 0.250 \\
\hline Juc Cr & 368 & 0.143 & 372 & 0.078 & 526 & 0015 \\
\hline$L y s-c 0$ & 526 & 0.085 & 633 & 0.009 & $J 20$ & $0.0+3$ \\
\hline Lys-Cu & 620 & 0.047 & 620 & 0.037 & 622 & 0.004 \\
\hline
\end{tabular}

Also, it was found that, the type of metal affect the UV-visible spectra in different mole fractions of ethanol. This can be noted from the values of absorbance which decrease in the following order: $\mathrm{L}(\mathrm{Zn})>\mathrm{L}(\mathrm{Ni})>\mathrm{L}$ $(\mathrm{Co})>\mathrm{L}(\mathrm{Cu})$, where $\mathrm{L}$ is ligand.

\subsection{Adsorption of methylene blue}

The synthesized $\mathrm{NiO}$ nanoparticles were tested for removal of $\mathrm{MB}$ dye from aqueous solution. Adsorption capacity, adsorption isotherms, adsorption kinetics and mechanism of adsorption of MB by synthesized NiO nanoparticles were studied. The adsorption capacity (qe, mg dye/g adsorbent) and the dye removal $\%$ at different time intervals were determined at $25^{\circ} \mathrm{C}$ as explained in page (69) and their values are presented in (Tables 14). Adsorption of MB on the synthesized metal oxide nanoparticles at different times were showed in (Fig. 17).

The results show that, the adsorption capacity and the removal percentage increase as the contact time increase. 
Table 14. Adsorption capacity (qe) and dye removal percentage at different time intervals for adsorbents at $25^{\circ} \mathrm{C}$

\begin{tabular}{|l|l|l|l|l|l|l|l|l|}
\hline \multicolumn{2}{|l|}{ Time, Minute } & 30 & 60 & 90 & 120 & 150 & 180 & $\mathrm{q}_{\max }$ \\
\hline \multirow{2}{*}{$\mathrm{NiO}$} & qe, mg/g & 4.68 & 4.75 & 4.78 & 4.81 & 4.86 & 4.95 & \multirow{2}{*}{4.95} \\
\cline { 2 - 8 } & $\%$ Removal & 91.1 & 92.6 & 93.2 & 93.7 & 94.7 & 96.5 & \\
\hline
\end{tabular}

The rate of percentage adsorption is higher in the initial stages because adequate surface area of the adsorbents is available for the adsorption of Methylene Blue. As time increases, more amount of MB is adsorbed onto the surface of the adsorbents and surface area available decreases.



Fig. 16. UV-Visible spectra curves of $\left(\mathrm{Co}^{+2}\right)$ complex in (ethanol-water) mixtures with different mole fraction of ethanol $(0.00-0 \%$, $0.235-50 \%$ and $1.00-100 \%)$ at $25{ }^{\circ} \mathrm{C}$

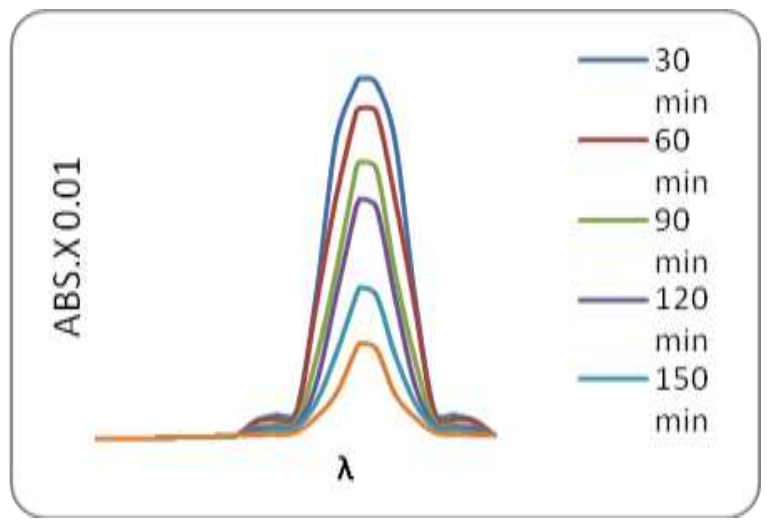

Fig. 17. Adsorption of $M B$ on the synthesized $\mathrm{NiO}$ nanoparticles at different times

\subsection{Adsorption isotherms}

To find the most appropriate model for the methylene blue adsorption, data were fitted to Langmuir [35],Freundlich [36] and Temkin[37]isotherm models, respectively. Results revealed that Langmuir adsorption isotherm was the best model for the methylene blue adsorption onto adsorbents with correlation coefficient of R2 $=1$. The Langmuir model describes the adsorption as a monolayer onto surfaces having finite number of identical sorption sites. From the Langmuir adsorption isotherm, the value of the maximum adsorption capacity $\left(\mathrm{q}_{\max }\right)$ was calculated and presented in (Table 14). The values of $\left(\mathrm{q}_{\max }\right)$ are equal the values after $180 \mathrm{~min}$ which indicate that the optimum contact time is $180 \mathrm{~min}$.

\subsection{Kinetics isotherms}

Kinetic models; pseudo-first order, pseudo-second-order kinetics model and intra-particle diffusion model were applied to investigate the mechanism of adsorption. Results show that the pseudo-second-order model kinetic isotherms were the best model for the methylene blue adsorption onto adsorbents with correlation coefficient $\mathrm{R}^{2}$, close to unity.

\subsection{Specific surface area}

A method of measuring the external specific surface area of metal oxides is described. Basic of methylene blue dye in dilute aqueous solution is applied at room temperature and adsorption isotherm is determined by spectrophotometric analysis of solution. The mode of adsorption is indicated by the type of isotherms. Methylene blue dye adsorption on metal oxides follows Langmuir adsorption isotherm. Specific surface area (SSA) has been calculated from equation and found to be $15.71 \times 10^{-3} \mathrm{Km}^{2} / \mathrm{Kg}$.

$$
\mathrm{S}_{\mathrm{MB}}=\mathrm{Q}_{\max } \cdot \mathrm{a}_{\mathrm{MB}} \cdot \mathrm{N}_{\mathrm{A}} \cdot 10^{-20} / \mathrm{M}
$$


Where $\mathrm{S}_{\mathrm{MB}}\left(\mathrm{Km}^{2} / \mathrm{Kg}\right)=$ Specific surface area of the synthesized metal oxide, $\mathrm{Q}_{\max }$ is maximum adsorption capacity, $\mathrm{a}_{\mathrm{MB}}=$ occupied surface area of one molecule of $\mathrm{MB}, \mathrm{N}_{\mathrm{A}}=$ Avogadro's number and $\mathrm{M}=$ molecular weight of MB.

\section{CONCLUSION}

Complexes derived from metal acetates with lysine amino acid were synthesized and characterized. Lysine chelate metals through amino nitrogen and carboxylate oxygen., the solubility of complexes decrease as mole fraction of ethanol increase. Thus, the solvation process of complexes decrease as mole fraction of ethanol is increase. The density of complexes is slightly decreased as mole fraction of ethanol increase. Thus, the solvated volume of complexes decrease as ethanol mole fraction increase. Ly-Ni(II) is the precursor to synthesize $\mathrm{NiO}$ nanoparticles by calcination at $800{ }^{\circ} \mathrm{C}$. Nanoparticles characterized using XRD and TEM. Adsorption of MB on the surface of nanoparticles giving the value of adsorption capacity 27.2 $(\mathrm{mg} / \mathrm{g})$, also used to remove dyes from wastewater.

\section{REFERENCES}

[1] Li, Y., Cui, L., Li, Q., Jia, L., Xu, Y., Fang, Q. and Cao, A. Novel symmetric amphiphilic dendritic poly (L-lysine)-b-poly (L-lactide)-b-dendritic poly(L-lysine) with high plasmid DNA binding affinity as a biodegradable gene carrier. Biomacromolecules., 8, 1409-1416, 2007.

[2] Naik, S. S., Ray, J. G. and Savin, D. A. Temperature and pH-responsive self-assembly of poly (propylene oxide)-b-poly(lysine) block copolymers in aqueous solution. Langmuir., 27, 7231-7240, 2011.

[3] Lee, Y. and Kataoka, K. Bio-signal-sensitive polyion complex micelles for the delivery of biopharmaceuticals. Soft Matter., 5, 3810-3817, 2009.

[4] Zhang, L. Jiang, Y. Ding, Y. Povey, M. D. and York, J. Investigation into the antibacterial behaviour of suspensions of ZnO nanoparticles (ZnOnanofluids). Nanopart. Res., 9, 479-489, 2006.

[5] Caputo, T. Lisi, L. Pirone, R. and Russo, G. On the role of redox properties of $\mathrm{CuO} / \mathrm{CeO} 2$ catalysts in the preferential oxidation of CO in H2-rich gases. Appl. Catal. A: Gen., 348, 42-53, 2008.

[6] Zhou, K. Wang, R. Xu, B. and Li, Y. Synthesis, characterization and catalytic properties of CuOnanocrystals with various shapes. Nanotechnology., 17, 3939, 2006.

[7] Nair, M. T. S. Guerrero, L. Olga Arenas, L. and Nair, P. K. Chemically deposited copper oxide thin films: structural, optical and electrical characteristics. Appl. Surf. Sci., 150, 143-151, 1999.

[8] Szu, S. and Cheng, C. L. Sol-gel-derived percolative copper film. Mater. Res. Bull., 43, 2687-2696, 2008.

[9] A. P. Alivisatos. Semiconductor Clusters, Nanocrystals, and Quantum Dots Science., 271, 933-937, 1996.

[10] Manna, L. Scher, E. C. Li, L. and Alivisatos, A. P. Epitaxial Growth and Photochemical Annealing of Graded CdS/ZnS Shells on Colloidal CdSeNanorods. J. Am. Chem. Soc., 124, 7136-7145, 2002.

[11] Mlondo, S. N. Revaprasadu, N. Christian, P. Helliwell, M. and O'Brien, P. Cadmium thiosemicarbazide complexes as precursors for the synthesis of nanodimensional crystals of CdS. Polyhedron., 28, 2097-2102, 2009.

[12] Kato, M. and Suzuki, N. J. Excess volumes of binary mixtures containing acetylacetone. Chemical Thermodynamics., 10, 435-440, 1978.

[13] Vogel A. I. “A Text Book of Quantitative Inorganic Analyses', 2nd Ed.,Longman, London, 1961.

[14] Tripathi, I. P. and Kamal, A. Synthesis, characterization of some complexes of copper (II) with 1asparaginine, 1 histidine and 1-lysine. American Journal of Advanced Drug Delivery, 3, 95-103, 2015. 
[15] Sung, D. J., Robert. A. and Condrate, S. I.R. spectra of lysine adsorbed on several cationsubstituted montmorillonites. Clays and Clay Minerals., 20, 79-82, 1972.

[16] Nakamoto, K., Morimoto, Y. and Martell, A. E. Infrared spectra of aqueous solutions-I. Metal chelate compounds of amino acids. American. Chemical. Society., 83, 4528-4532, 1916.

[17] Ferraro, J. R. Chapter1. Low Frequency Vibrations of Inorganic and Coordination Compounds. New York. Plenum press, 1971.

[18] Gottlieb, H. E., Kotlyar, V. and Nudelman, A. NMR Chemical Shifts of Common Laboratory Solvents as Trace Impurities. Inorganic Chemistry., 62, 7512 -7515, 1997.

[19] Cakir, S., Coskun, E., Naumov, P., Bicer, E., Bulut, I., Icbudak, H. and Cakir, O. Synthesis, spectroscopic and thermal studies of the copper(II) aspartame chloride complex. Molecular Structure., 608, 101-107, 2002.

[20] Coats, A. W. and Redfern, J. P. Kinetic Parameters from Thermogravimetric Data. Nature., 201, 68-69, 1964.

[21] Horowitz, H. W. and Metzger, G. A. A New Analysis of Thermogravimetric Traces. Analytical Chemistry., 35, 1464-1468, 1963.

[22] Hosny, N. M. Synthesis and spectral characterization of Schiff-Base complexes derived from alanine and 2-acetylpyridine with some divalent metal acetate. Coordination Chemistry., 60, 27552764, 2007.

[23] Hussien, M. A., Nawar, N., Radwan, F. M. and Hosny, N. M. Spectral characterization, optical band gap calculations and DNA binding of some binuclear Schiff-base metal complexes derived from 2-amino-ethanoic acid and acetylacetone. Molecular Structure., 1080, 162-168, 2015.

[24] Hosny, N. M. $\mathrm{Cu}(\mathrm{II}) \quad$ and $\mathrm{Zr}(\mathrm{IV})$ Complexes with $(E)-N-$-(1-(pyridine-4yl)ethylidine)nicotinohydrazide. Synthesis and Reactivity in Inorganic Metal-Organic and NanoMetal Chemistry., 406, 391-396, 2010.

[25] Hosny, N. M., Hussien, M. A., Radwan, F. M. and Nawar, N. Synthesis, spectral characterization and DNA binding of Schiff-base metal complexes derived from 2-amino-3-hydroxyprobanoic acid and acetylacetone. Spectrochimica Acta Part A: Molecular and Biomolecular Spectroscopy., 132, 121-129, 2014.

[26] El-Dossoki, F. I., Gomaa, E. A. Excess refractive index, polarizability, polarization and the molar volume of some mixed solvents. Indian Chemical Society., 82, 1, 2005.

[27] Wadi, R. K. and Vinita, R. K. Partial molar volumes and viscosities, of some monovalent ions in ethanolamine and water-ethanolamine mixtures at 298.15 K., Indian Chemical., 39A, 598-602, 2000.

[28] Millero, F. J. Apparent molal expansibilities of some divalent chlorides in aqueous solution at 25.deg. Physical Chemistry., 72, 4589-4593, 1968.

[29] King, E. J. Volume changes for ionization of formic, acetic, and butyric acids and the glycinium ion in aqueous solution at 25.deg. Physical Chemistry., 73, 1220-1232, 1961.

[30] Schmidt, F.C., Hoffman, W. E. and Schaap, W. B. The Determination of the Apparent Molal Volumes and Viscosities of Some Electrolytes in Anhydrous Ethylenediamine at $25^{\circ} \mathrm{C}$. Proceedings of the Indian Academy of Sciences., 72, 127, 1962.

[31] Copal, R. and Siddiqui, M. A. Study of ion-solvent interaction of some tetraalkyl ammonium and common ions in N-methyl acetamide from apparent molal volume data. Physical Chemistry., 73, 3390, 1969.

[32] El-Dossoki, F. I. Refractive index measurements of the solvent-solvent interaction, the polarization and polarizability of some mixed solvents. Chinese Chemical Society., 54, 1129, 2007. 